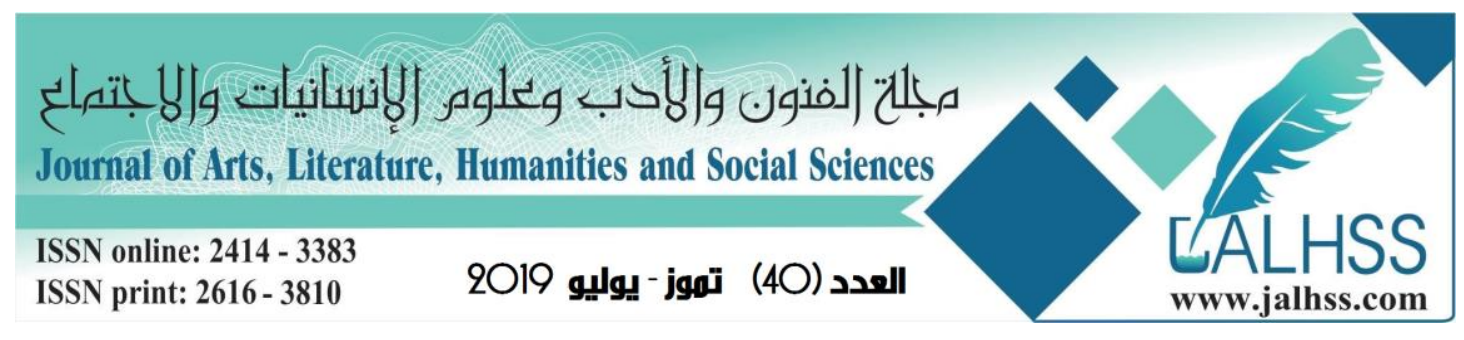

\title{
The Possibility of Promoting Sustainable Development in Iraq Kurdistan Region - Kurdistan Region by Imposing VAT
}

\author{
Dana Khalid Smail \\ College Administration \& Economics \\ Lebanese French University \\ Kurdistan Region - Iraq
}

\begin{abstract}
The economic reality of Iraq - the current Kurdistan region many of the problems need more thought and effort and treatments, and among the most important of these problems the subject of a single budget and the dependence on a single resource is oil in the financing of public expenditure, and dependence on one source and specifically oil is accompanied by many complexities And risks, including the difficulty of relying on one source at the source, as well as the multiple problems facing the oil source in terms of the recent price decline on the one hand, as well as the problems of export and terrorist operations on the other.

And the diversification of sources of funding the budget and not rely on one source approach adopted by most oil-producing countries and adjacent to Iraq in particular, as the United Arab Emirates and Iran and other countries, several steps that reduced the proportion of dependence on oil in financing budget expenditures and reached many From other sources, so that they are better able to cope with the crises caused by lower oil prices or different global crises.

Iraq and its natural resources granted by God and the human resources and other resources provided by the ability to diversify the sources of financing the budget without dependence on oil as a single source, and the methods that contribute to this area is the imposition of value added tax in Iraq - This tax is levied on domestically produced goods and services and includes activities carried out by natural and legal persons who are subject to taxation and imposed on imported goods and services, whether in their country of origin or otherwise.

Undoubtedly, the value added tax represents an important economic burden for all the countries adopted decades ago, and now comes at a time when Iraq - Kurdistan Region is in urgent need according to many developments and benefits.
\end{abstract}




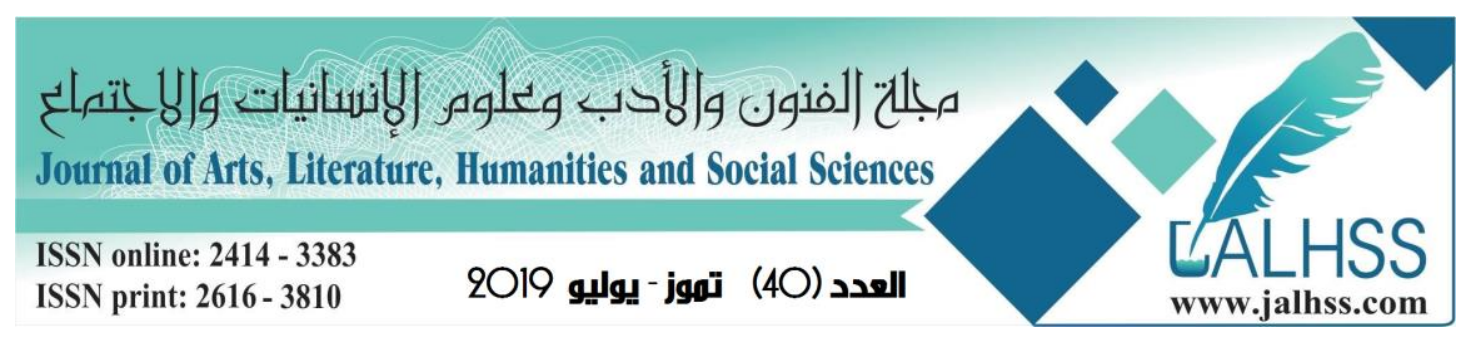

\section{Introduction:}

Government authorities rely on a range of fiscal policy tools to achieve economic and social goals. These tools can be categorized into general sections, including revenue and expenditure. Revenue tools include many components, but the most important role is played through tax policy.

Taxation is a prominent place in all financial systems of the world, as an important source of funding for the state budget, as well as being used as a major tool for economic and social change. They are clearly used to channel investments and their growth and economic stability, as well as the use of taxes as an important means of directing public and private consumption and reducing unnecessary consumption, as well as a fair redistribution of national income commensurate with the country's economic and social Objectives.

The tax system in any country must conform to the legal, social and economic relations prevailing in it, but changing the development of economic and social relations and changing economic conditions with changes in the global economic system require a radical reform of the existing tax system commensurate with internal and external changes so that tax becomes an important tool in addressing Many economic and social problems.

As the Iraqi economy is moving towards a market economy and economic openness, new strategies must be adopted to reform the tax system. There should be a degree of response to the taxes imposed in accordance with the economic changes, which will lead to activating the role of taxes in financing in line with the new orientations of the economy. Important sources in financing the state budget. This study attempts to highlight the role of taxation in financing through an analytical study of the taxes imposed and their suitability to the political, economic and social conditions and the possibility of reforming the current tax system.

\section{Problem of the Study:}

As the revenues of the natural resource extracted and the source (oil) represent the proportion of revenues more than the general budget in Iraq - Kurdistan Region, these revenues have not been tight in terms of rent, and means a single public budget in Iraq - Kurdistan Region by relying on oil in light of increasing public expenditure by the low prices Oil, on the other hand, the consequent need to seek alternative alternatives to finance the public budget.

In this area, the problem of research can be formulated in answering the following question:

Does the imposition of value added tax in the treatment of a single budget in Iraq Kurdistan Region? 


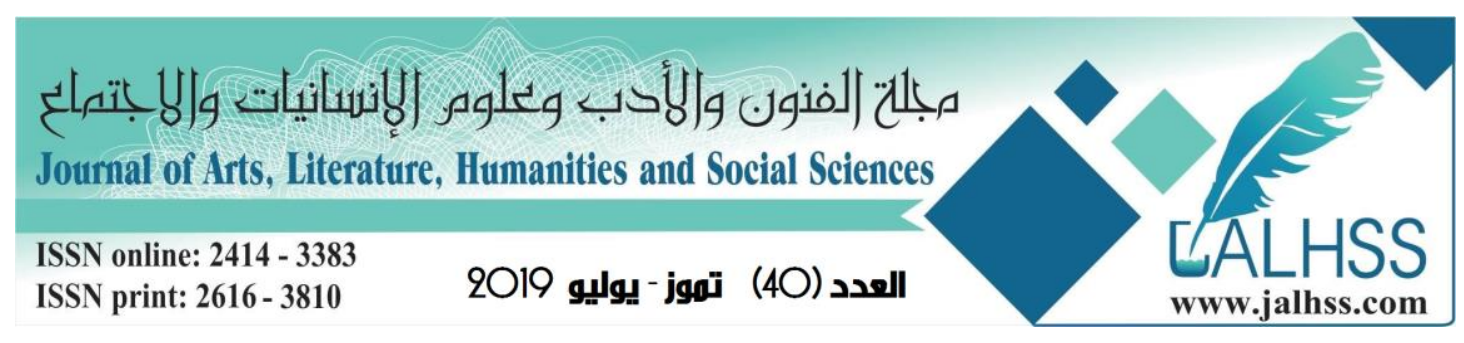

\section{Importance of the study:}

The research derives its importance from the importance of taxation as one of the important sources of funding for the general budget of the state. The start of the process of economic correction requires activation of the role of sovereign revenues, especially tax, to improve its role in financing the public budget.

\section{Objectives of the study:}

The research aims to achieve the following:

- Identify the current reality of the unbalanced budget in Iraq - Kurdistan Region.

- Clarifying the risks of mono-balancing on the economy Iraq - Kurdistan Region

- Clarifying the concept of the application of VAT.

\section{Significance of the Study:}

Search is built on the premise the following (there is a significant positive relationship between the adoption of value-added tax and reduce single budget)

\section{The second topic Literature Review}

Among the most prominent studies and research on the subject of this research address a number of studies:

A study presented to the Council of the Higher Institute for Accounting and Financial Studies, University of Baghdad, entitled "Analysis of the development of indirect taxes in Iraq and its role in financing." The research starts from the hypothesis that the indirect tax effect of financing is low and not used As a tool to redistribute incomes. The researcher concluded that the tax policy of the 1980s was characterized by weak impact, while its role was increased during the decade of the siege, specifically after 1995 because of its adoption by the state as an important financing tool due to the absence of the oil supplier, although this role was not effective Enough to achieve the objectives of tax policy during the siege. Therefore, the role of tax policy should not neglect the existence of oil revenues, but should remain an important source of aviation, This research is close to our research in dealing with one aspect of the tax system - indirect taxes

Study (Ibrahim, Mohsen, 2007)

Ph.D. in Economic Sciences Introduction to the Faculty of Management and Economics - University of Sulaymaniyah entitled "Evaluation of the Effectiveness of the Tax System in Iraq for the Period (1980-2005), the study dealt with the problem of imbalances suffered by

The Iraqi economy during the study period such as the budget deficit of the state, the state of economic instability, and the existence of large disparities in the distribution of incomes and wealth, which showed clearly the underdevelopment of the tax system 


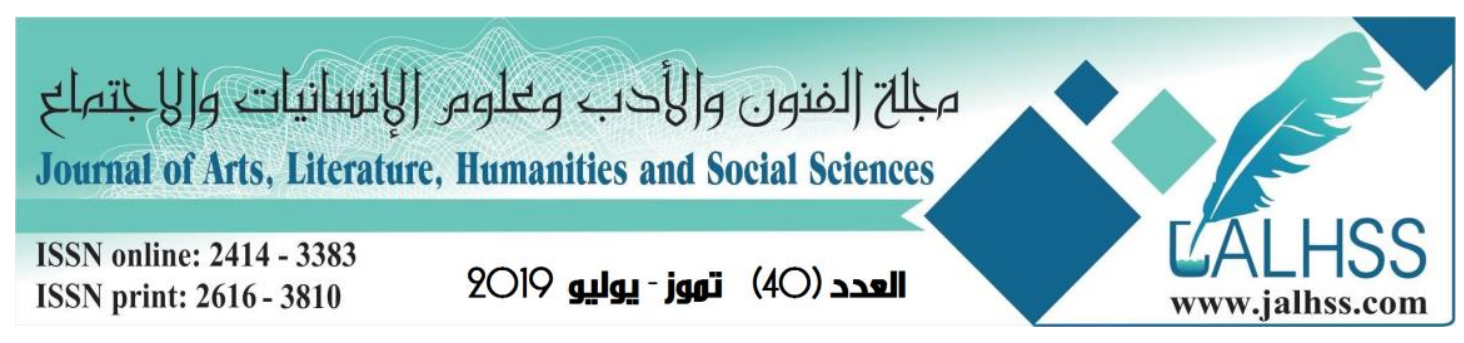

in Iraq, and the implications for economic policies in general and financial, especially in achieving its objectives.

The researcher concluded that the most important of these is that although the funding role is one of the main objectives or functions that the tax system seeks to achieve in any country, tax revenues are the last of the sources of funding.

Study (Mohamed, Abbas Mohamed and Abdel-Jabbar, Anas 2007)

The study is based on the hypothesis that the acceleration of the movement of economic change in Iraq towards a market economy will lead to the integration of Iraq with a new structure of a new economic system. New tax policy. The study discussed the need for financial reform as an essential part of the economic reform process and is similar to our research in calling for tax reform and activating the role of taxes in financing the state budget. Without access to the joints of the tax system in Iraq during the period (1990-2005), both direct and indirect taxes, and did not discuss the study to analyze the relative importance of these taxes.

\section{The concept of budget single}

The dilemma of the economy of Iraq - the Kurdistan region is widening with the continuation of price declines in crude oil prices and the inability of the government to provide alternative financial resources to support the budget and the economy. This coincides with a ferocious war with gangs calling for an open-ended funding not an austerity budget. The double shock (oil and terrorism) facing Iraq - the Kurdistan Region is forced to adapt to the scarcity of resources and activate alternative economic sectors such as industry, agriculture and tourism and stimulate the private sector, not only to finance the budget but also to absorb unemployment and the operation of idle capacity and reduce the dependence of almost total imports in the coverage Domestic need of goods and services (Hamid, 2015: 24).

Where the oil sector in Iraq - Kurdistan Region is the dominant and the largest contributor to the GDP over the past five decades of the twentieth century and the decade of the twenty-first century so that the energy of Iraq - Kurdistan Region of oil production is the only determinant for access to resources Iraq - Kurdistan Region The resources derived from oil were not used for the development of the non-oil sectors through: the agricultural sector, the activation of the tax system, expansion of the industrial base, raising the living standards of the population, expansion of the construction and development of the tourism sector.

All that contributed and contributed by other resources in the financing of the budget was limited between 6-8\%, which is a shy contribution that can not be relied on in any way and is unable to withstand any problem that may be exposed to the country. Incidentally, this ratio with its modest, Most of these taxes are due to income taxes due to their owners as a result of contracts and enforcement of the state departments. The source of funding and the state services, as is well known, depends on the oil 


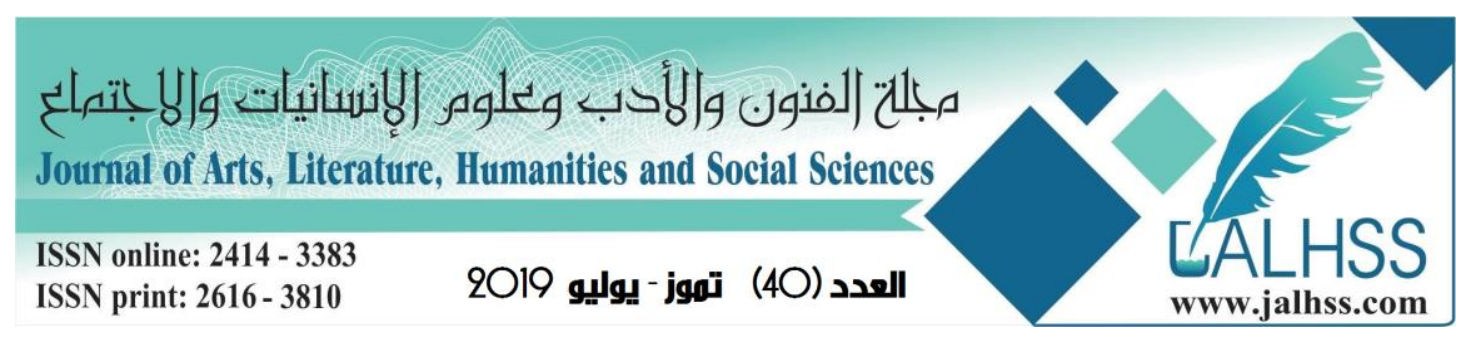

resources, which is indirectly caused by oil. And here lies the danger and if this source is exposed to any emergency does not forgive God, it will be very dangerous and risk the present and future of the country and even the lives of his people.

The almost absolute dependence on the oil sector in financing government spending and the general budget of the state put Iraq - Kurdistan Region in the category of rent economies, and its development and failure is governed by the stability of world oil prices and volatility, which is ultimately subject to international wills. The oil sector contributes to the formation of $96 \%$ of the gross national income and the financing of more than $93 \%$ of the state budget, resulting in the desired improvement in economic growth will be subject to increased foreign exchange earnings achieved by oil exports, or the deterioration of oil imports will lead to Increase the budget deficit.

Oil is the most important source of energy and today provides about $40 \%$ of the world's needs, but it is surrounded by many risks, including:

- The possibility of securing supplies for the world and the risks of diversification of energy sources.

- Political risks and risks inherent in the conflict between the world's major powers on the sources

Main production of oil. (Bassam, 2014: 16).

- Most importantly, the risk of depleting world oil reserves due to high levels of consumption

Which currently exceeds the growth rates of world oil reserves.

The conviction of the people of Iraq-Kurdistan Region is that the financing of public expenditure of the government is through the proceeds of the sale of oil, and this belief was reflected on the officials in the State of Iraq - Kurdistan Region and became their main concern to find a link between the complete oil revenues and the government economy, Oil is an important role in the financing of the Iraqi government - Kurdistan Region but it is not true that the economy of the country fully to this role, many countries do not have oil or any natural wealth, yet its economy is prosperous and its people live in great well-being, I took the $b$ The liberation of its national economy from dependence on oil revenues, and dozens of years ago, Iraq Kurdistan Region launched the slogan of the use of oil revenues in development, but this slogan remains empty of its content so far, the annual oil revenues go down in vain every year without benefiting the economy Iraq - Kurdistan is a real benefit and became what enters the difficult currencies of the country leaking out of various forms, even if the previous governments acted rationally with the oil revenues would have been Iraq - Kurdistan now has hundreds of billions of dollars in the Central Bank, but the continuation of the fatal mistake funded by Hypocrisy of oil revenues missed this opportunity on Iraq - Kurdistan Region, and it is very unfortunate that the adoption of the budget for the current year 2017 this error with determination. 


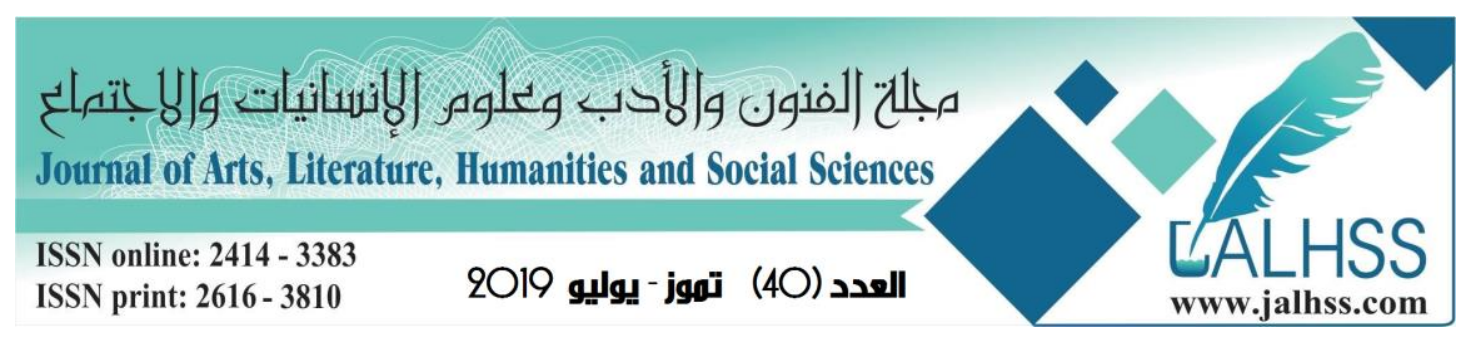

The elimination of this error requires restructuring the financing of the public budget according to the type of government expenditure in accordance with the trend and that government expenditure is divided into two types, external and internal. External spending represents the amounts required to cover external commitments such as compensation for the war in Kuwait and international obligations and purchases of essential non-locally available needs such as weapons and medicines, and economic estimates indicate that the volume of this spending is up to (30) trillion dinars during the last year 2016, which requires spending in dollars, and the main source of the dollar is oil revenues, while internal spending includes Amounts required to cover local government obligations such as salaries, compensation and purchases of local needs (statistics of the General Secretariat of the Council of Ministers), which is supposed to include paragraphs of the budget how to manage this spending and recovery within an active economic cycle aimed at boosting local production and increase the incomes of the people of Iraq - And the operation of the unemployed and the provision of services instead of the poor procedures such as austerity and forced savings, the local financing does not mean a return to the policy (print currency) anarchy that occurred in Iraq - Kurdistan Region in the nineties of the last century Praise the economic blockade This policy is completely unacceptable, as it means a violation of the independence of the Central Bank of Iraq - Kurdistan Region, which must remain protected to maintain foreign currency balance for future generations and ensure the strength of the economy Iraq - Kurdistan Region, the restructuring of funding the budget requires the adoption of the cash cycle The correct one of the budget errors). Hamed, 2015: 12)

There is the possibility of benefiting from the import of taxes in light of the vast oil wealth enjoyed by Iraq - Kurdistan Region: This widespread concept is one of the misconceptions that constitute part of what can be called metaphorically (culture of revenue) or rentier as called in the economic dictionary, These revenues are accompanied by other concepts that fall under this culture, most notably consumer spending and luxury and the unbridled desire to enjoy what was not possible.

\section{Second: The importance of searching for alternatives to finance the budget:}

The financial element has become a major reason for the success of any country in the world and the preservation and good use of public funds is a necessary and important requirement to maintain the power of the state. Despite the costs that the State will pay for its preparation and implementation, its advantages will be greater than its cost. The confrontation with it, and the desire of Iraq - Kurdistan Region to reach the ranks of the world countries have been obliged to know their resources and control their expenses, and this is through the general budget.

The general budget is defined as: a list of deliberate detailed estimates of the uses and resources of the state for the next financial year, which is the means through 


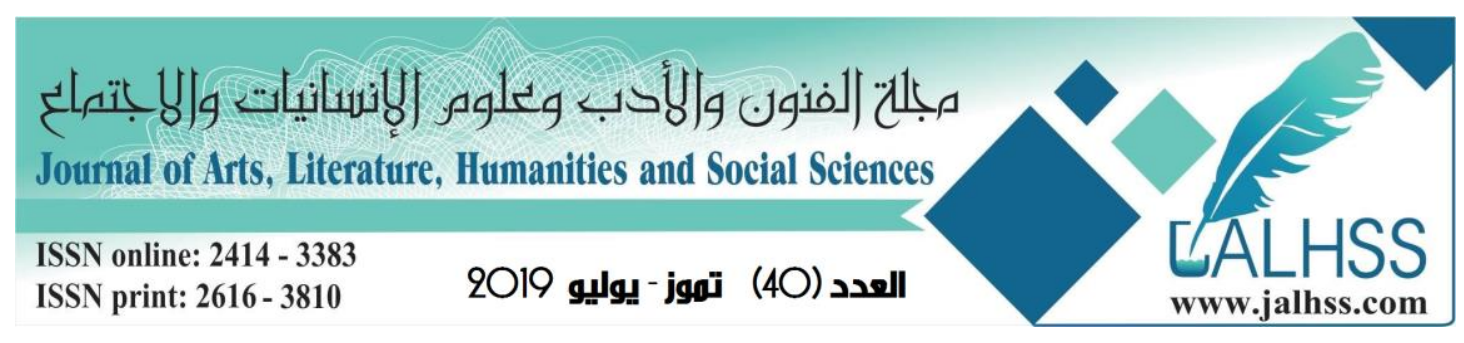

which to extrapolate the state's political, economic and social trends and future plans. It is therefore a reflection of the hopes and economic renaissance of the state. These include all income to be collected and all expenses to be disbursed during the fiscal year beginning on 1 January and ending at the end of December of each year. The state's final account also shows what was actually done during the year to show the reality of the state's financial position.

It is noted that there is an increasing importance of the role of the public budget in any country in the development of performance in public organizations, where the budget is one of the main reasons for any achievements and obstacles to the development of public performance, so the budget is still the constant interest of States and by "The budget of the state is considered a major tool for economic and social development. The budget and its preparation constitute a fundamental factor in enriching the policy and developmental effort and addressing the needs and priorities of development. The general budget tries to give a broad idea of all the Government revenues and expenditures. "The expansion of the role of states in economic and social life, and the development of the level of development in the current era, has led to important changes in the concept and content of the budget, this is no longer the only way to limit the needs of the government and public revenues of funds to accomplish its limited tasks, Other functions are almost essential, especially as a preferred means to control the fiscal policy of the state and achieve its objectives and implementation of economic policy, the budget has become closely related to the economy of contemporary countries, and this is the most important features that distinguish the modern budget from the budget Traditional society.

It has been shown by tracking the financial situation in Iraq - Kurdistan Region Absence of the strategic vision of the financial policies when preparing the budget is one of the main reasons for the failure of the economy of Iraq - Kurdistan Region during the previous years, has absent economic programs from the doors of expenditure and government revenues included in the budgets of previous years, Despite the oil savings achieved by the country until 2013, in favor of the dramatic increase in operating expenses (consumer) on the one hand, and weak control over the management and implementation of investment expenditure efficiently. It is essential that future budgets include economic programs that reflect the reality of the Iraqi economy - the Kurdistan Region and the nature of the economic and financial crisis experienced by the country because of unilateral exports, and establishes a new pattern in the management of the economic file tends to diversify resources and stimulate economic sectors of agriculture, industry and tourism and promote the private sector to reduce unilateralism Economy Iraq - Kurdistan Region and chronic dependence on the oil resource. The current financial shock could be an opportunity for financial reorganization, tightening public money control, fighting corruption and reducing unnecessary expenses that the government has been forced to pay by oil revenues. 


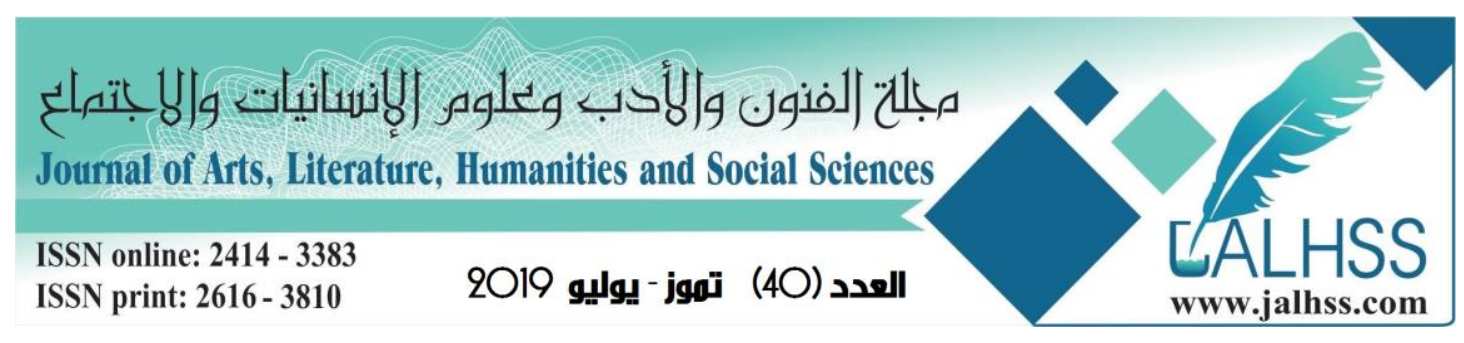

The current situation requires the government to take several measures, most notably: controlling government spending and reforming the tax system through the enactment of a number of laws that contribute to the expansion of tax funds and the establishment of new tax rates consistent with the capacity of the citizen, taking into account the lack of burdens on the poor and middle classes, The restructuring of stateowned industries and the gradual transition to the private sector, as the previous budgets reveal that the support and financing of these industries did not improve their economic performance, most public projects are still overwhelmed by losses. As for the activation of non-oil sectors, this requires a plan to diversify sources of revenue by stimulating the non-oil sectors in the country (Al-Bassam, 2014: 13)

That taxes can play a large role in supporting the state budget and try to address the monopolization of the budget or reduce the effects and falls within the objectives that can be achieved through the activation and reform of the tax system, as well as other objectives that can be achieved by taxes and the guidance of the movement of capital and projects (Tax) to achieve social goals such as redistribution of income among the social strata for social security.

And that the tax system in Iraq - Kurdistan Region is one of the oldest tax systems in the region, has been able to achieve the goal of funding at the time despite the modest economic structure at the time .. At present, the leaders of fiscal policy to prepare plans for tax reform to ensure the upgrading of the work of this sector Important in the form that makes it able to achieve its objectives to the fullest.

It is worth mentioning that modern financial thought does not deny the objective of the financial tax, which has become of great importance with the increase of the needs of the state and the expansion of its activities, but it rejects the idea of tax neutrality because of its impact on various economic variables, including social, so added modern thought economic and social objectives of tax .

Therefore, the financial objective of the tax may be contrary to its economic or social objectives. In this case, it should be a priority, as a principle and a basis, but some think that the financial objective should not be a priority for the state to reflect its economic and social policy. Despite the importance of these policies, the state can achieve them without reference to taxes. But the state can not find a substitute for taxes as the main source of revenue. Therefore, in the case of differences and inconsistencies between the different objectives of the tax, the priority of the financial target must be at the expense of the other objectives. It remains one of the most important tools to provide public revenues due to the abundance of revenues. Of financing from loans and cash issuance, as well as the non-inflationary nature of financing by tax (Nasser, 2003, 105).

Thus, the importance of the financial aspect of taxation is highlighted in two interrelated and indivisible aspects: the provision of financial resources to achieve sustainable development. On the other hand, the provision of these resources through 


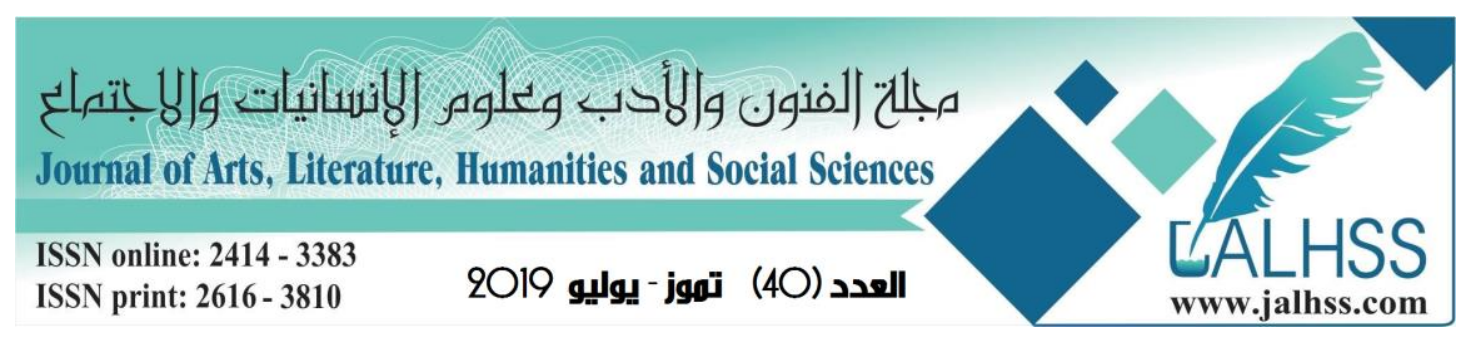

taxation in general and VAT in particular contributes to the provision of resources that contribute to Reduce reliance on oil as the sole source and resource base.

\section{Third: The theoretical framework for VAT}

\section{(1) the concept of VAT}

VAT is levied on the value added to domestically produced goods and services and includes the activities of natural or legal persons (taxable), as well as to imported goods and services (whether taxable in their countries of origin or otherwise) (Amin, 2002: 26) The details of the application of this tax or the exemption from it vary from state to state and from one activity to another, and this tax is imposed on the increase in the value of goods and services at each stage of production and circulation, and is seen on the other hand as a tax on consumption to be fulfilled at each stage Economic cycle, applied according to the quantity Consumption, that is, they attach to the value paid by the consumer. If so, that is, a consumption tax, the question of why it might be called "value added tax" may be questioned rather than "consumption tax" (Hobeika, 2000: 9)

The imposition of a tax on the final goods means that they are imposed on the individual commodity several times during the stages of formation. To avoid this, the tax is imposed on the different stages of production to ensure that the taxes are not repeated. Therefore, the tax is imposed on the product at each stage of production regardless of the use of this product, To ensure that the final consumption tax is levied, the tax on goods and services used as input to the production process should be returned to those who purchased the goods. This tax, which is based on the principle of the return of taxes on intermediary goods, (Cumbers, Andrew, 2006: 56).

The tax concept of value added differs from its economic concept, whether at the macro or micro level. Thus, the value added tax is not actually levied on value added. In spite of its name, however, it is intended (in the end and generally) Is the tax on income when it is spent, that is, a tax on consumer spending, and is charged to the final consumer (at purchase), which is the last link in the process (production, exchange, consumption), and is different from the consumer spending tax known to receive payments in Each stage of economic activity, and hence the loss Value added tax is not levied on the value added (in its recognized economic sense), but is imposed on the total value of the sale. Taxpayers must, at each stage of production or distribution, calculate the value of this tax on the total value of production and add it to the selling price. (Tax authorities) after deduction of the payment made in the previous stage (Amin, 2002: 38). Thus, this tax applies to production at all stages but only affects the value added to the value of production, Between the price at which goods and services are produced and produced Costs of productive users used in the production of these goods and services at each stage of production (war, 1999: 142). 


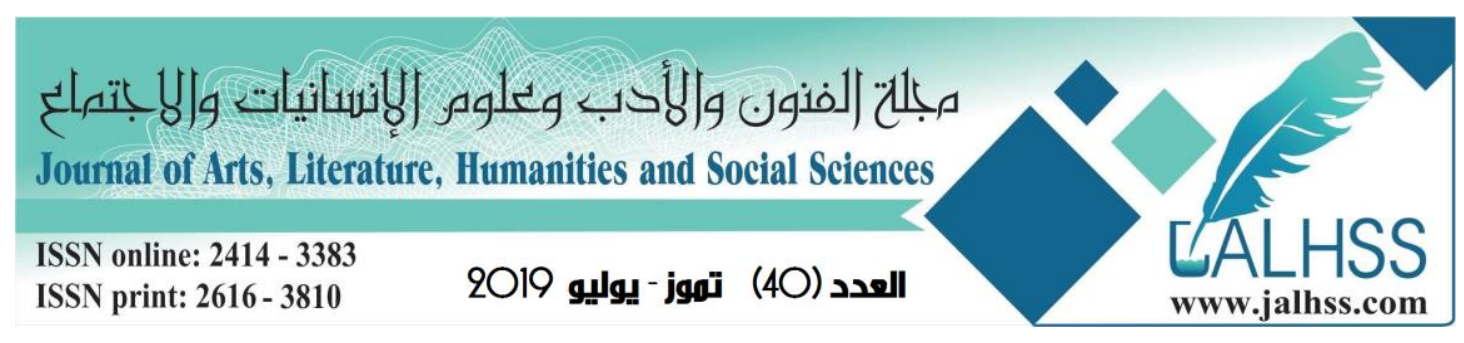

Through the above concept, VAT can be defined as a tax on the consumption of goods and services imposed within the territory of the State (concerned with their application), whether produced locally or imported?

To illustrate the concept of value added, it must be emphasized that each production process is based on the use of available resources. In each production process, it is assumed that economic value is added to the original value of the resources used in the production process. The first step in considering production activity is economic activity, Value added) that represents the economic value added to the original value, (discussion, 1997: 165) that is:

Value added $=$ final production value - the original value of production inputs Although there are many differences in the structure and application of VAT, there is general agreement on some key issues: (Loo \& Hansford, 2005: 56)

- The prevailing view tends to make consumption the ultimate value-added tax container.

- VAT, which requires the refund of tax on capital goods, does not lead to any price distortions such as that faced by producers when buying and selling from one another.

- A desirable feature is to maintain the efficiency of production (ie, the value-added tax does not exclude the economy from the limits of its productive potential) (Cumbers, Andrew, 2006: 38).

- In view of VAT levied on each stage of production, ensuring that it is loaded only on consumption also requires the return of full production inputs, and the value chain is free of any interruptions in its sequence. Exemption from production inputs leads to such interruption (Shaoul, 2005: 44)

Reasons for increasing interest in VAT issue:

Many governments prefer to apply this tax because of its abundant earnings and as an alternative to many other taxes. It is an indirect tax on the consumption of goods and services that are ultimately borne by the consumer, but are met at each stage of the economic cycle of these goods and services from the production stage through the distribution stage to the consumption phase. The same taxpayer collects and collects the tax according to certain criteria Then pay them to the tax authorities.

In recent years, the principle of value added tax has been adopted in many developing countries as part of the tax reform programs advocated by the International Monetary Fund (IMF), which has helped its experts in the past decades to apply the principle of tax in many countries, including South Korea, Mexico and South Africa And Hungary. Among the first Arab countries to apply the tax were Morocco (1986) followed by Tunisia in 1988, Egypt in 1990, Algeria in 1992, Mauritania in 1995, Jordan in 2001 and Lebanon in 2002, Experiences and Issues, 2005: 29.

The interest in this tax, in addition to supporting the revenues of the state, comes for several reasons, including: (Harbi, 2014: 25) 


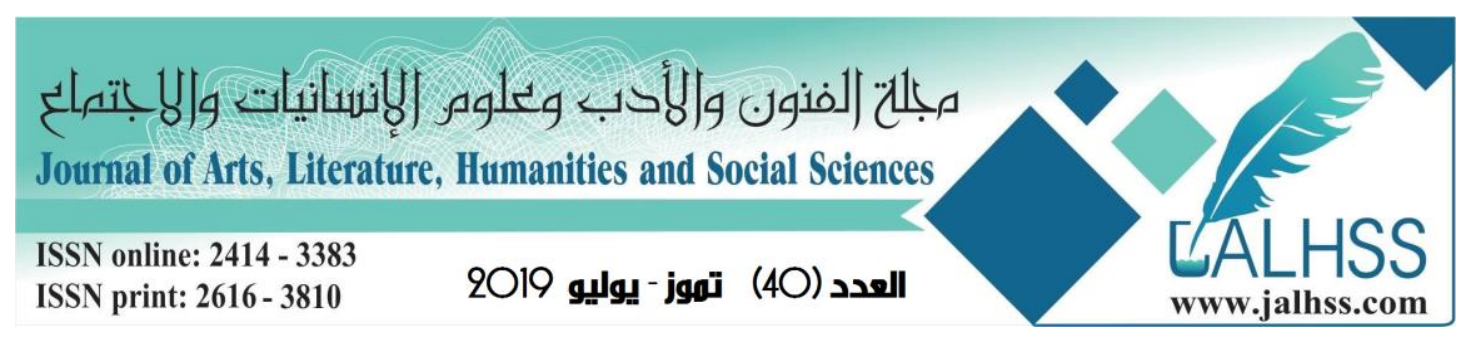

- The spread of its use in most countries of the world, it is applied in about 150 countries around the world. The United States is the only exception among OECD countries where this tax is not applied.

- The expected high return on this tax, which represents on average $19 \%$ of the total tax revenues of various types to OECD countries, and rises in the country of Chile to about $40 \%$. With a return of $6.4 \%$ of the GDP of the OECD countries. In Denmark, its revenues are about $10 \%$ of GDP.

- Use it as a means of protection for local industries against imported products, as the imposition of this tax restates customs tariffs on imports, but in other ways correspond to WTO regulations.

- Encouraging exports, as they are imposed on domestic sales only, and their elimination on exports is a strong incentive for producers to export.

\section{Forth: Attributes and principles of the VAT}

The basic features of VAT are:

- It is a tax with a large pot imposed on multiple stages of production, with the deduction of taxes on production inputs from taxes on production outputs, and this is the most important feature ((This means that while traders are required to collect the tax on all their sales, they also have the right to claim a discount The taxes they have on their production inputs (Loo \& Hansford, 2005: 56).

- Tax is the best in terms of economic efficiency and the reduction of tax evasion, if the infrastructure is available to apply (and difficult to provide in many developing countries) (Fiscal, 2010: 39).

- The large variation in the structure and rate of VAT in the countries where it is currently applied; this can be seen in the countries where it is applied. For example, the standard VAT rate is higher in Western Europe and the transition economies than in other countries, Asia and the Pacific, and VAT features, are the most complex in Western Europe, North Africa and the Middle East, in terms of the number of rates in force. Further analysis shows that countries where VAT has been introduced are relatively advanced, The value of VAT in promoting sustainable development, the proportion of international trade to GDP is relatively high, and countries that do not apply VAT, the population of $30 \%$ of which is less than one million (experiences and issues, $2005: 27$ ).

The common impression of the success of VAT is that the impression that VAT has been successful is that only 5 countries have abolished its application. For the future, VAT is likely to play a fundamental role in many parts of the world, Where revenue outcomes are addressed because of the continuous liberalization of trade (Amin, 2000: 34).

- There are a number of features that governments see in VAT:

- It increases the tax power and provides abundant revenues to the public treasury for the breadth of its scope and comprehensiveness. In principle, it imposes on everything 


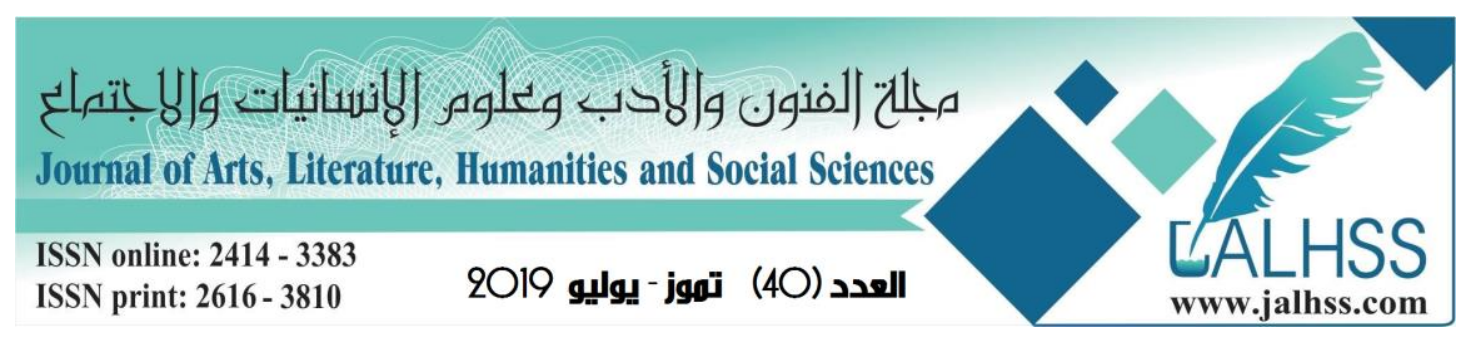

and everything, before it excludes, reduces and exempts, and thus imposes a wide range of goods and services. VAT was at varying levels in the countries that applied it, out of total tax revenues in some countries (50\%), in Argentina (51.4\%), in France (17\%) and in Arab countries Between (17.9\%) in Egypt and (31\%) in Algeria, for example (25.3\%) in Tunisia, (22.7\%), J Morocco, (23.3\%) in Mauritania (testing issues, 2005: 112).

- Fast collection and supply to the public treasury after a short period of maturity or the occurrence of the incident that creates it.

- Flexible and convenient to the general treasury, it increases with the increase of economic activity, and is not affected much in the recession.

- It is a control instrument on income taxes. It checks the income taxes in a double way by comparing data on VAT with data on income taxes (2010: 42).

Fifth: Value Added Tax according to the opinions of the supporters and opponents:

(1) Supporters of VAT: supporters of the imposition of value added tax

Advocates of value added tax (VAT) and its proponents have many advantages when imposing this type of tax. The most important of these are: (Penguin, 1999: 247), (Hamdan, 1999: 26).

- Economists prefer to design this tax to be a tax on consumption, that is, the main impact is to widen the gap between the price paid by the consumer of the commodity and the price received by the seller from the sale of it, contrary to popular opinion, the tax burden in this case not only the consumer but bear The seller is a part of it.

- Value added tax is levied on the different stages of production. Taxes on inputs are taxed on products or outputs. This means that sellers are required to tax all their sales and at the same time they can claim for taxes imposed on them. The goods that they used as inputs in the production process. The advantage is that revenues are guaranteed by collecting them during all production processes, as opposed to taxes on retail sales (Barakat, 2003: 135). This type of tax does not distort production decisions as it is The case is in need Bears the final revenue (McLaren.J, 2003: 71).

- It is a neutral tax because it does not limit the tax burden to a certain stage of production, and it helps to encourage exports because it is usually not imposed on exports (Debate, 1997: 41).

Also, the tax burden borne by domestic goods is equal or comparable to the tax burden borne by imports (McLaren J., 2003: 53).

- From the administrative point of view, VAT introduces the principle of self-control among registrars, which facilitates the work of the tax administration and reduces the possibility of tax evasion. If the money supplier or the service provider wants to reduce the tax on it (Daniel, 2005: 45) Who buys the full amount of the amount into the purchase list so that by exercising the right of deduction he can benefit from the tax he paid. On the other hand, if the buyer exaggerates when preparing the lists of the value of the tax paid, it is in the interest of the money-changers or service providers to 


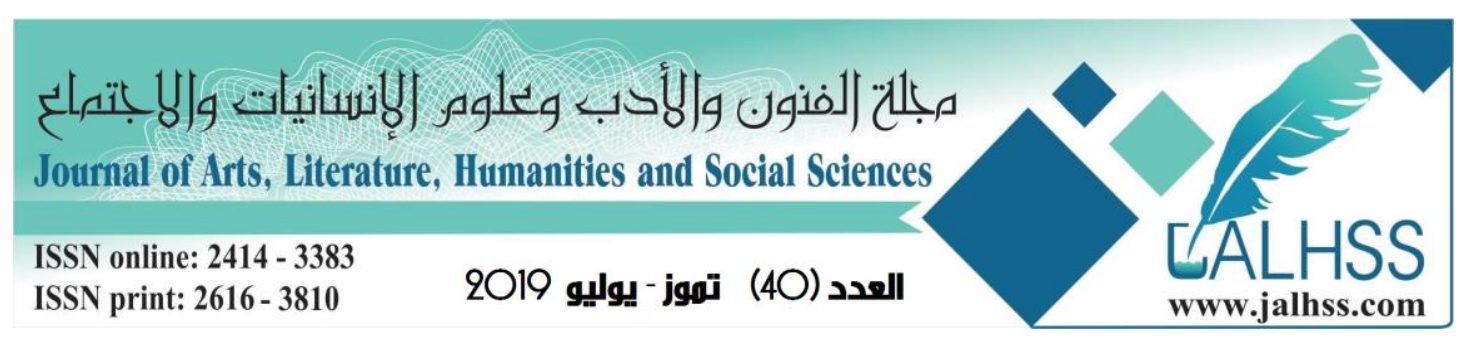

register the real tax to avoid payment of more than the amount of tax actually owed to them Shaoul,2005:32).

\section{Part two Practical side: Tax accounts VAT account}

In the later stage of the business dealings, these traders sell their imported goods, either to intermediaries or to end consumers. This confirms the possibility of identifying the VAT parameters and carrying out the registration process for all important importers. Value Added Tax (VAT) In the border, the input balance (factors of production) will be zero. VAT will therefore be payable on the total value of the sales. If VAT is paid in the border area, Worden, when it is allowed to be a balance against the VAT due for sales returns.

The first procedure for the design and imposition of value added tax is the formulation and preparation of VAT legislation. This law should ensure that the widest possible tax base is maintained in order to achieve the highest revenue revenue by an acceptable rate of VAT, The law is the type of privileges and tax exemptions strictly, and as part of the design of VAT, it is necessary to decide if a uniform ratio or multiple ratios are dependent on VAT. As for the proposed percentage within the VAT design, it is a single ratio and applied to taxpayers Which is relatively low compared with the rates calculated in the various Arab countries that apply, especially Tunisia, Egypt, Algeria, Jordan and Morocco, and the design of VAT should include the decision that the application of this tax will apply all goods, materials and services produced in Iraq - Kurdistan, or there are exceptions, and all these represent important issues with complex social and economic scale.

There are several options for the design and implementation of VAT, and the actual design of the provisions should be detailed in a manner commensurate with the nature of business activities in Iraq - Kurdistan Region. Even if this happens, VAT will have a significant impact on businesses, including most companies and craftsmen Individual traders and other individual businesses. Therefore, in Iraq - Kurdistan Region there is only one important decision. This decision is to put an end to the mandatory duty to register for value added tax.

The first procedure for the implementation and imposition of value added tax is to determine the method of the value added tax system and applies to all goods and materials consumed in Iraq - Kurdistan Region, in this regard can be referred to two methods, the first method is built, assuming that the value added tax follows the principle of place The second option is the application of VAT on all goods, materials and services produced in Iraq - Kurdistan Region in accordance with the principle of origin. However, the second method involves significant disadvantages for the competitive situation of Iraq World trade, as this method requires the application of value-added tax on crude oil exports, for example, we will not remain there is a need 


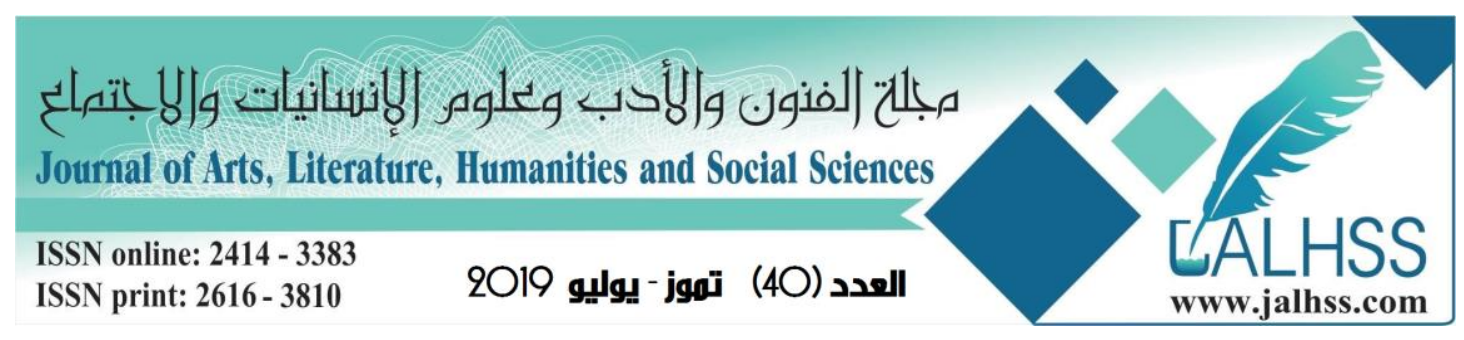

for the existence of differences in the internal trading transactions under these versions of the value-added tax, but in the treatment of only exports and imports.

The adoption of a value-added tax of a consumptive nature in accordance with the method or principle of the place of destination requires the law to impose VAT on all imports and recover the export tax, within the local processing series for all losses, materials and services (as shown in the following page).

VAT can be calculated in two ways:

- Determine the value added by the product to its final products compared to the value of its purchases and then tax it, ie the purchase of goods and services from the net sales, and then tax the remaining balance.

- The calculation of the tax on the total sales for a specified period, then excluding the tax paid by the economic unit or the project on its purchases of goods and intermediate products and capital equipment and other, which were paid from the previous stages, this means offsetting the tax paid on purchases against the tax paid on sales.

Before we start calculating the tax, we will define the tax terms related to the VAT calculation: Before we start calculating the tax, we will define the tax terms related to VAT calculation:

- Basic value: value of the item before the imposition of the tax.

- amount of tax: the tax, which is the ratio of the value of the underlying value

- The total value: value of the item or service after tax (ie the total base value and the amount of tax)

- Tax amount $=$ basic value $\times$ tax rate

- Total value $=$ base value + tax amount

- Amount of payment = Total of tax included - Total out of tax

- Profit = amount to pay $\mathrm{x}$ inverted tax rate

The following information concerning the lists of sales and purchases, were obtained from the records of the company $(\mathrm{Q})$, which operates the general trade and registered tax department.

Sales Lists

5/ 1/2004 50 tons of sugar were sold for 8 million dinars, including the tax for Nineveh Company on the account and the sales list No. 20.

$15 / 110$ tons of sugar were sold in the amount of $1600000 \mathrm{JD}$ in cash including the tax and the sales list No. 21.

23/1 Ten tons of flour were sold for 20000 dinars, not including the tax on the list No. 22 on the account for Basra.

$30 / 150$ tons of rice were sold at a price of 195000 dinars per ton, including the tax on the list No. 23.

$31 / 11000 \mathrm{~kg}$ of tea was sold at 2500 dinars per $\mathrm{kg}$, including the tax in cash on the list No. 24. 
مبلحت (لفنون والأدب وعلوه الإنسانيات والبانتهاع

Journal of Arts, Literature, Humanities and Social Sciences

ISSN online: 2414 - 3383

ISSN print: $\mathbf{2 6 1 6}-\mathbf{3 8 1 0}$

\section{العدد (40) تموز - يوليو 2019}

B. Purchase lists and purchase returns

1/1 Purchase of 30 tons of flour The price of the ton 150000 dinars, including the tax from the company Euphrates, and payment in cash list 15.

$5 / 1$ The purchase of 60 tons of sugar in the amount of seven billion and two hundred million dinars of Al-Aqsa Company on the list 201.

$8 / 1$ was purchased 70 tons of rice price of 25 thousand dinars dinars does not include the tax from the star company list 535.

19/1 Purchase of 3000 liters of oil Price per liter 1000 dinars does not include the tax from the company star list 596.

30/1 Purchased $1000 \mathrm{~kg}$ of soap Price of $\mathrm{kg} 1500$ dinars does not include the tax from the camel company in the list No. 237.

31/1 Company returned to the company star 20 tons of rice list No. 77 .

In order to determine the amount to be paid, a list of receipts and payments is prepared (Hobeika, 2000: 89).

The receipts side: Sales - Sales returns - Credit notification (debit discount)

Payment side: Purchases - Purchase returns + Expenses - Debit notification (discount earned)

a) Receipt detection

\begin{tabular}{|l|r|l|r|r|r|}
\hline Date & No. list & \multicolumn{1}{|l|}{$\begin{array}{l}\text { The } \\
\text { statement }\end{array}$} & \multicolumn{1}{l}{$\begin{array}{l}\text { The amount } \\
\text { of tax }\end{array}$} & Basic value & \multicolumn{1}{|l|}{ Total value } \\
\hline $5 / 1$ & 20 & List sale & 800000 & 8000000 & 8800000 \\
\hline $15 / 1$ & 21 & List sale & 160000 & 1600000 & 1760000 \\
\hline $23 / 1$ & 22 & List sale & 200000 & 2000000 & 2200000 \\
\hline $30 / 1$ & 23 & List sale & 975000 & 9750000 & 10725000 \\
\hline $31 / 1$ & 24 & List sale & 250000 & 2500000 & 2750000 \\
\hline & & & 2385000 & 23850000 & 26235000 \\
\hline
\end{tabular}

Total incoming tax 2385000

Detect payments

\begin{tabular}{|r|l|r|r|l|l|}
\hline Date & No. list & $\begin{array}{l}\text { The } \\
\text { statement }\end{array}$ & $\begin{array}{l}\text { The amount } \\
\text { of tax }\end{array}$ & Basic value & Total value \\
\hline $1 / 1$ & & $\begin{array}{r}\text { List } \\
\text { purchase }\end{array}$ & 450000 & 4500000 & 4950000 \\
\hline $5 / 1$ & 201 & $\begin{array}{r}\text { List } \\
\text { purchase }\end{array}$ & 720000 & 7200000 & 7920000 \\
\hline
\end{tabular}




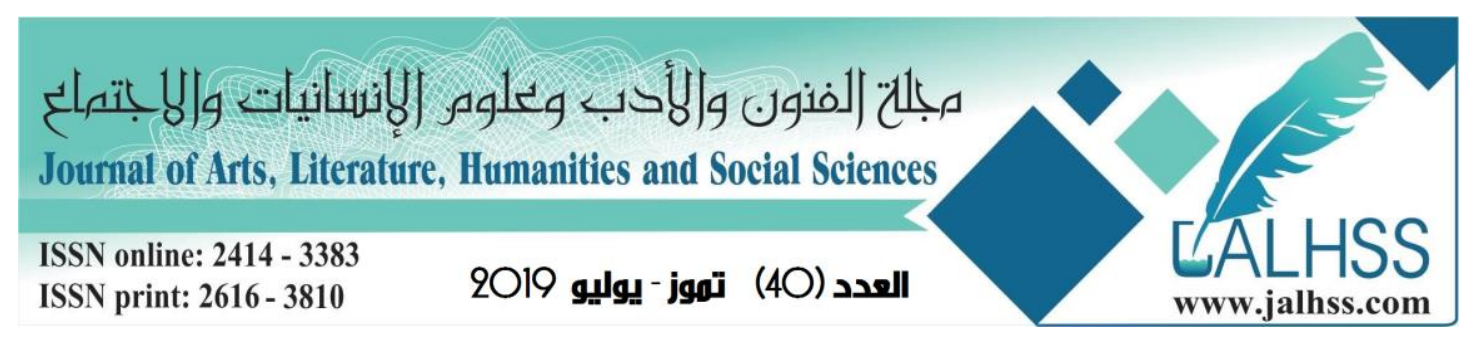

\begin{tabular}{|r|r|r|r|r|r|}
\hline $8 / 1$ & 535 & $\begin{array}{r}\text { List } \\
\text { purchase }\end{array}$ & 175000 & 1750000 & 1925000 \\
\hline $19 / 1$ & 596 & $\begin{array}{r}\text { List } \\
\text { purchase }\end{array}$ & 300000 & 3000000 & 3300000 \\
\hline $31 / 1$ & 237 & $\begin{array}{r}\text { List } \\
\text { purchase }\end{array}$ & 150000 & 1500000 & 1650000 \\
\hline & 77 & $\begin{array}{l}\text { Purchase } \\
\text { returns }\end{array}$ & $500000-$ & $5000000-$ & $5500000-$ \\
\hline & & & & 17450000 & 1919500 \\
\hline
\end{tabular}

Total external tax $2385000-1745000=640000$ dinars

And that the amount of the difference represents the amount that is added to the general state budget, which could help provide revenue to fund the general state budget.

\section{Conclusion:}

The following conclusions were reached:

This study presents a set of findings on the single treatment budget in the region of Kurdistan Iraq.

1. All the public budgets of Iraq were only a function of oil prices and the volume of exported quantities, and here lies the need to verify and review the fragility of the Iraqi economy - Kurdistan Region, which suffers from the imbalance of the productive structure and unilateral proceeds of public revenues.

2. Iraq - Kurdistan Region has many economic resources (natural, human and financial) if exploited efficiently can contribute to the activation of sources of non-oil income that will diversify the components of the gross national product and reduce the risk of oil price, and contribute to finding means of hedging that Make the general budget of Iraq more secure and stable and independent of the dominance of one of the resources of the general budget, including the activation of the tax system and the creation of tax containers such as VAT.

3. Tax policy plays a crucial role in diversifying budget sources as an important source of public finance. Value-added tax is an important economic contributor to all the countries that have adopted it for decades and now comes as Iraq The Kurdistan Region is in urgent need according to the latest developments and many benefits, as such tax is also used in the efforts to diversify the sources of income in Iraq Kurdistan Region under a series of policies should be adopted in order to move away from dependence on oil as a main source of income, For a while Two years ago and until now. 


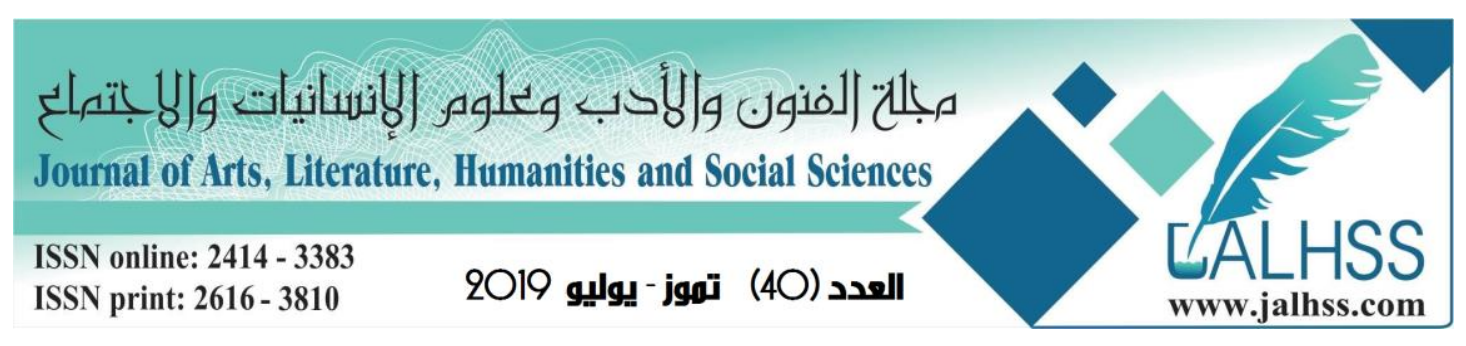

4. When talking about value added tax, the role of government finance is also highlighted - a stable, just and efficient form through:

- Mobilization of revenues: The first element of the success of economies is the mobilization of revenues, which preoccupies many policy makers, and higher government revenues create the necessary financial space for maneuver and allow spending to achieve sustainable development. In addition, the more stable revenues help to attract the volatility of public expenditure and fiscal policy in line with the periodic trends of the oil-exporting countries, which clearly highlights the significant impact of Iraq - Kurdistan Region in light of the fluctuation and decline in oil prices.

\section{Recommendations:}

1. It would be useful for Iraq to consider in depth the experience of countries that applied VAT. The issue is complex, and it is not related to the goods to be taxed, but to the mechanism of collection as well as return to the beneficiaries, etc., under the following two elements:

- The first element is the ability of countries to generate large government revenues, which contribute to mono-balancing.

The second element of the success of economies in the twenty-first century is the international tax system, which is a necessary means through which Governments can mobilize their revenues in a globalization-dominated economy.

- In other words, we need a tax system in which the average citizen is convinced that all companies, including multinationals and wealthy individuals, contribute a fair share of the government portfolio for the public good.

2. Since the law on the imposition of value added tax is supposed to achieve justice on the one hand (as justice is one of the most important tax rules), and ensures that the state treasury is provided with funds representing the income derived from the imposition of this tax on the other hand, so the formation of a committee to prepare a draft project The law should include experts, specialists and researchers in the field of tax work, employees representing the financial authority, and representatives of the categories of taxpayers, such as the Union of Iraqi Industries - Kurdistan Region, the Federation of Chambers of Commerce and the Union of Businessmen.

3 - Value Added Tax can be implemented in Iraq - Kurdistan Region by starting to develop a simple system focusing initially on VAT and increasing the focus on corporate taxes as well as real estate tax and fees as well as continue to invest in building specialized capacities in tax administration so that it can achieve what This requires the regularity of employees in the General Authority for Taxation and its branches in training courses that precede the issuance of the new law and are attached thereto.

4. Encouraging taxpayers to perform their tax duties in accordance with the provisions of the law on a voluntary basis by raising tax awareness among them. This should not be limited to the taxpayers, and should be extended to the sectors and institutions of 


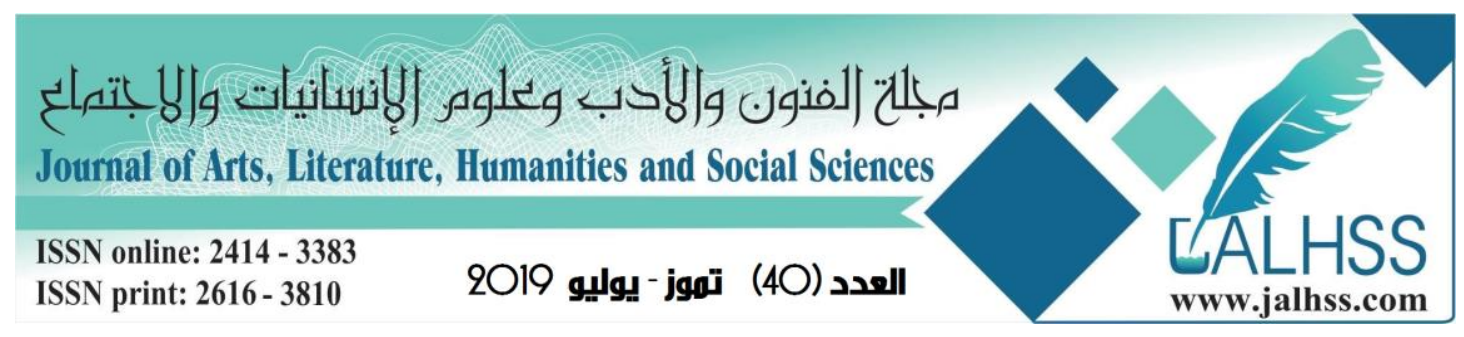

the state and society as a whole, based on the importance of the national dimension of taxation. Its performance is a national and moral duty based on the principle of social solidarity. The society as a whole is responsible for ensuring that this duty is fulfilled by all those involved. This requires the concerted efforts of religious and social, political, academic and professional organizations to promote tax awareness and education. $\mathrm{P}$ the importance of social solidarity and the importance of tax and objectives in achieving public welfare and development and economic development.

\section{References:}

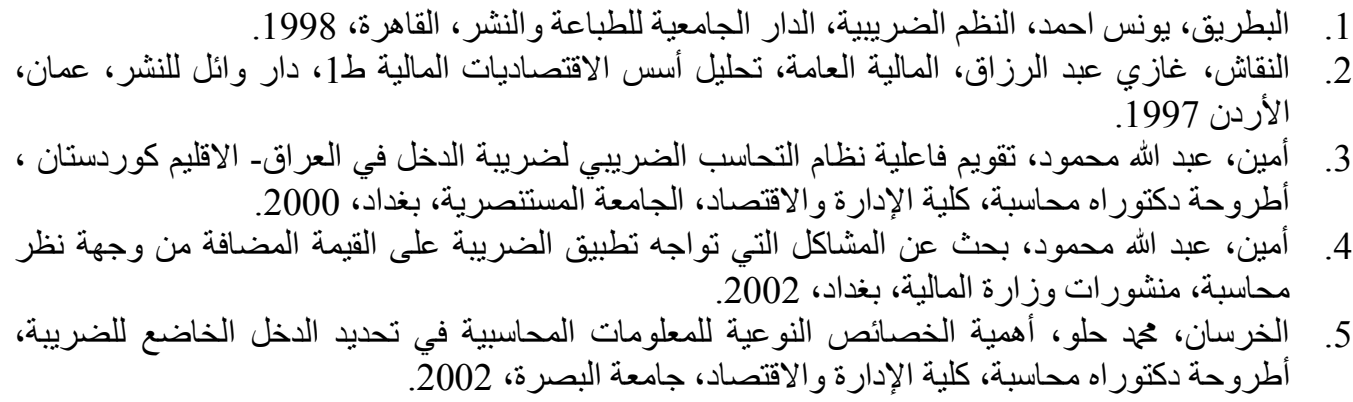

6- Cumbers, Andrew and Birch, Kean, Public Sector Spending and Regional Economic Development: Crowding out or Adding Value, University of Glasgow, Center for Advanced .Studies, UK. January 2006

7-bCorinne Gendron, Le Development Durable Comme Compromise, University du Québec, .Canada, 2006

8- Conditions, Conference De Rome, La Taxes Sur la Value Agouti : Experiences et Entex, .Conference sure la TVA du Dialogue Fiscal International, Rome, Mars 2013

9-Daniel, I. Mitchell, Beware the Value - Added Tax, Heritage Foundation. U.S.A. 200

10- Edwards, William, Developing an Income Statement for a Value - Added Farm Business, .Lowa State Extension Economist, Heady, 2006

11- James Bickley, Value - Added Tax as a New Revenue Source, Congressional Research Service, Public Finance Review, VOL.25, No.3, U.S.A. 2005

12- Loo. Ec, M. Kerchar M \& Hansford, International Comparative analysis of self .assessment, what Lesson are there for Tax Administration, Australian Tax Forum, 2005 